\title{
Transcriptional activity of the hamster $C Y P 11 B 2$ promoter in NCI-H295 cells stimulated by angiotensin II, potassium, forskolin and bisindolylmaleimide
}

\section{J G LeHoux and A Lefebvre}

Department of Biochemistry, Faculty of Medicine, University of Sherbrooke, Sherbrooke, Quebec, Canada J1H 5N4

(Requests for offprints should be addressed to J G LeHoux)

\begin{abstract}
We studied the regulation of the hamster $C Y P 11 B 2$ gene in the NCI-H295 cell line, which is known to produce aldosterone in response to stimulation by angiotensin II (AII) and $\mathrm{KCl}$. Ten deletion plasmids harboring the $5^{\prime}$-untranslated region of the CYP11B2 gene were used for chloramphenicol acetyltransferase (CAT) assays. Transient transfections showed progressively increasing basal promoter activity by constructs beyond the TATA box, with a peak occurring with the $-167 \mathrm{bp}$ construct which contains putative Ad1, Ad2, Ad5 and the newly reported $-143 /-161$ cis-element sequences. The promoter activity was lower with the construct containing the putative $\mathrm{Ad} 3$ cis-element and increased with longer constructs. This indicates the presence of both inhibitory and stimulatory ciselements in this area of the gene. Expression of the reporter gene of all constructs was stimulated by AII and $\mathrm{KCl}$, with the exception of the construct containing only the TATA box, which showed 6 -fold and 10-fold increases occurring with the $-167 \mathrm{bp}$ deletion plasmid. The patterns of increase in CAT activity with $\mathrm{AII}$ and $\mathrm{KCl}$ treatment were similar, showing that these two regulators can stimulate hamster $C Y P 11 B 2$ promoter activity through common cis-elements. The calcium channel antagonist nifedipine blocked the stimulatory effects of $\mathrm{KCl}$ on CAT activity, showing the involvement of calcium channels in the regulation of CYP11B2 gene transcription by $\mathrm{KCl}$. 12-OTetradecanoylphorbol 13-acetate, a known stimulator of the protein kinase $\mathrm{C}$ (PKC) signaling
\end{abstract}

pathway, was without significant effect on CAT activity. Bisindolylmaleimide, a specific inhibitor of PKC, had a significant enhancing effect (3.4to 6-fold), indicating that PKC may negatively regulate the expression of the hamster $C Y P 11 B 2$ gene in NCI-H295 cells. A mutation was induced in the sequence $-143 /-161$ of the $-350 \mathrm{bp}$ construct in order to determine its importance in the regulation of hamster $C Y P 11 B 2$ promoter activity. The stimulatory effects of $\mathrm{AII}, \mathrm{KCl}$, forskolin and bisindolylmaleimide on CAT activity were significantly less in the mutant than in the wild type. These results confirm that this cis-element is necessary in maintaining a high level of transcriptional activity in stimulated NCI-295H cells. In conclusion, using NCI-295H transfected cells, we have found that the $5^{\prime}$-untranslated region of the hamster $C Y P 11 B 2$ gene possesses transcriptional activity with stimulatory and also inhibitory cis-elements; CYP11B2 promoter activity can be stimulated by AII, $\mathrm{KCl}$, forskolin, dibutyryl cAMP and bisindolylmaleimide. Our results suggest that this gene is positively regulated through the protein kinase A signaling pathway and through calcium channels, whereas PKC may have a negative regulatory effect upon the transcription of the $C Y P 11 B 2$ gene. Furthermore, we have shown that the cis-element $-143 /-161$ in the $5^{\prime}$-untranslated region of the hamster $C Y P 11 B 2$ gene is important in maintaining a high level of promoter activity in stimulated NCI-295H cells.

Fournal of Molecular Endocrinology (1998) 20, 183-191

\section{INTRODUCTION}

Adrenal steroidogenesis, by which mineralocorticoids and glucocorticoids are produced, involves numerous processes stemming from a common precursor, cholesterol (LeHoux et al. 1996a). The mineralocorticoid aldosterone is the product of three cytochrome $\mathrm{P} 450$ enzymes and 
a $3 \beta$-hydroxysteroid dehydrogenase (3$\beta$-HSD), whereas the glucocorticoid cortisol is the product of four cytochrome P450 enzymes and $3 \beta$-HSD. The final step in the synthesis of adrenal cortisol and aldosterone is mediated by two different enzymes in the adrenals of most animal species hitherto studied. The first, cytochrome P450 11 $\beta$-hydroxylase ( $\mathrm{P} 450 \mathrm{C} 11)$, the product of the CYP11B1 gene, is expressed in the zona fasciculata, yielding glucocorticoids. The second, cytochrome $\mathrm{P} 450$ aldosterone synthase (P450aldo), the product of the CYP11B2 gene, is expressed in the zona glomerulosa, yielding aldosterone. P450aldo possesses a strong $11 \beta$ hydroxylase activity and also 18-hydroxylase and 18-oxidase activities. This cytochrome mediates the 18-hydroxylation of corticosterone, yielding 18-hydroxycorticosterone, and then aldosterone (Miller 1988).

$\mathrm{P} 450 \mathrm{C} 11$ and P450aldo are present in hamster (LeHoux et al. 1994, Véronneau et al. 1996), human (Mornet et al. 1989), mouse (Domalik et al. 1991) and rat (Imai et al. 1990, Nomura et al. 1993) adrenal cortex, whereas in the bovine (Morohashi et al. 1990) and porcine (Yanagibashi et al. 1986) glands, a single protein expressed in both the zona fasciculata and zona glomerulosa is responsible for the last steps of gluco- and mineralocorticoid formation.

Previous studies have shown that $\mathrm{P} 450 \mathrm{C} 11$ and $\mathrm{P} 450$ aldo are differently regulated (Tremblay et al. 1991, 1992, LeHoux \& Tremblay 1992, Tremblay \& LeHoux 1993). Adrenal glucocorticoid formation is mainly under the control of adrenocorticotropin $(\mathrm{ACTH})$, whereas mineralocorticoid formation is primarily regulated by the renin-angiotensin system and potassium ions via the opening of calcium channels (LeHoux et al. 1996a). It has been shown that low-sodium and high-potassium diets can promote increases in P450aldo mRNA content and expression of its protein (Tremblay et al. 1991, 1992, LeHoux et al. 1996a,b). Low-sodium diets increase circulating angiotensin II (AII) levels via the reninangiotensin system (Tremblay \& LeHoux 1992).

A CYP11B2 gene encoding P450aldo was isolated from a hamster genomic library (Coulombe et al. 1996, 1997). When compared with the gene of other species, the 5 '-untranslated region (UTR) of the hamster CYP11B2 gene possesses conserved sequences similar to $\mathrm{Ad} 1, \mathrm{Ad} 2, \mathrm{Ad} 3, \mathrm{Ad} 4$ (also named SF-1) and Ad5 (Honda et al. 1990, Morohashi \& Omura 1990, Lala et al. 1992). Furthermore, footprinting analysis demonstrated an additional conserved sequence located in the hamster $C Y P 11 B 2$ gene between -143 and $-161 \mathrm{bp}$ (-143/-161) (Coulombe et al. 1996, 1997).

Using chloramphenicol acetyltransferase (CAT) assays, we previously studied the regulatory activity of the 5'-UTR of the hamster CYP11B2 gene in Y1 cells (Coulombe et al. 1996, 1997). These experiments demonstrated that the hamster CYP11B2 promoter was responsive to forskolin, indicating that the gene is controlled by the protein kinase A signaling pathway. We also reported that the cis-element $-143 /-161$ played a negative regulatory role in $C Y P 11 B 2$ gene transcription in Y1 cells. However, this cell line did not respond to stimulation by AII or potassium ions by controlling CYP11B2 promoter activity (Coulombe et al. 1996, 1997).

In the present study, we describe the regulation of hamster $C Y P 11 B 2$ promoter transcriptional activity in the NCI-H295 cell line. This cell line (Gazdar et al. 1990) was chosen because it expresses the three main pathways of adrenal steroidogenesis, namely mineralocorticoid, glucocorticoid and $\mathrm{C}_{19}$ steroid production, and because, in contrast with the $\mathrm{Y} 1$ line, it is responsive to potassium and AII in addition to forskolin (Bird et al. 1995). We found that hamster $C Y P 11 B 2$ promoter activity is stimulated by AII, potassium ions, forskolin, dibutyryl $(\mathrm{dBt})$ cAMP and bisindolylmaleimide; furthermore, in NCI-H295 cells, the cis-element $-143 /-161$ enhances transcriptional activity of the $C Y P 11 B 2$ promoter.

\section{MATERIALS AND METHODS}

\section{Deletion plasmids}

The pCAT basic vector (Promega, Madison, WI, USA) was modified by removing AP-1 and AP-1like cis-elements and adding two polyadenylation signal sequences upstream of the multicloning site (Coulombe et al. 1997). This modified vector was used to construct ten CYP11B2 gene deletion plasmids. These deletion plasmids were constructed to study putative Ad1, Ad2, Ad5 Ad3 and Ad4 cis-elements of the gene. As shown in Fig. 1, the shortest deletion plasmid $-63 \mathrm{bp}$ contained the TATA box only; the -83 bp contained Ad1; the $-102 \mathrm{bp}$ contained $\mathrm{Ad} 2$; the $-134 \mathrm{bp}$ contained Ad5; the $-167 \mathrm{bp}$ contained the recently reported new cis-element -143/-161 (Coulombe et al. 1997); the $-328 \mathrm{bp}$ contained Ad3; the $-350 \mathrm{bp}$ contained Ad4; the three other deletion plasmids contained respectively the first $-486 \mathrm{bp},-2458 \mathrm{bp}$, and $-3722 \mathrm{bp}$ of the $5^{\prime}$-UTR of the gene.

\section{Mutation of the $-143 /-161$ cis-element}

The sequence $5^{\prime}$-ggtaagacacttctactga- $3^{\prime}$ was changed to $5^{\prime}$-aagacatggtaccatagct- $3^{\prime}$ which comprised a KpnI site (underlined). To do so, PCRs were 


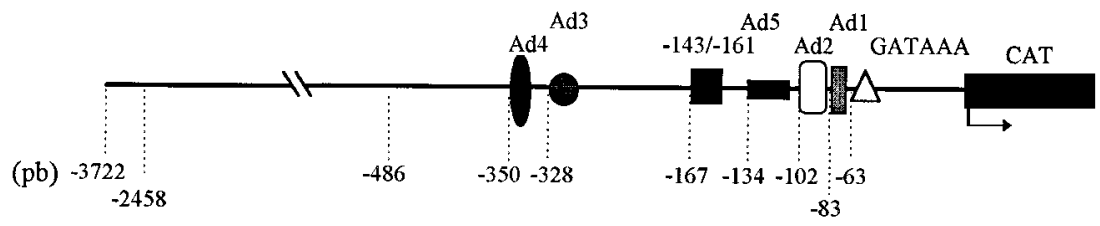

FIGURE 1. Schematic representation of the $5^{\prime}$-UTR of the hamster $C Y P 11 B 2$ gene. A series of deletion constructs containing progressively shorter fragments of the promoter region were prepared. These deletion plasmids were constructed in order to study putative Ad1, Ad2, Ad5, Ad3, and $\mathrm{Ad} 4$ cis-elements of the gene. The shortest deletion plasmid $-63 \mathrm{bp}$ contained the TATA box only; the $-83 \mathrm{bp}$ contained Ad1; the $-102 \mathrm{bp}$ contained Ad2; the -134 bp contained Ad5; the -167 bp contained the recently reported cis-element $-143 /-161$; the -328 bp contained Ad3; the - $350 \mathrm{bp}$ contained Ad4; the three other deletion plasmids contained respectively the first $-486 \mathrm{bp},-2458 \mathrm{bp}$, and $-3722 \mathrm{bp}$ of the $5^{\prime}$-UTR of the gene.

performed on the -350 construct (containing the putative Ad4 cis-element) using two sets of primers; first: 5'-catgcatgcagaaaccaaggtcttcta-3' (sense) with an SphI site and $5^{\prime}$-catggtaccatgtcttagctccctaatacc atccctc- $3^{\prime}$ (antisense) with a KpnI site; second: 5'atcggtaccatagctcaggtgagcccagctatg- $3^{\prime}$ (sense) with a KpnI site and $5^{\prime}$-catctgcagccctcctactctg tcg-3' (antisense) with a PstI site. The fragments were then digested with the corresponding enzymes and ligated with the pCAT vector digested with SphI and PstI.

\section{Cell culture}

NCI-H295 cells were maintained in Dulbecco's modified Eagle's medium/Ham F12 (1:1) supplemented with 1\% ITS Premix (Becton Dickinson Labware, Bedford, MA, USA), 2\% UtroSer SF (Bio Sepra SA, Villeneuve la Garenne, France), $200 \mu \mathrm{g} /$ $\mathrm{ml}$ streptomycin and $200 \mathrm{U} / \mathrm{ml}$ penicillin $\mathrm{G}$. Cells were grown at $37{ }^{\circ} \mathrm{C}$ under $5 \% \mathrm{CO}_{2}$.

\section{Transient transfections and CAT assays}

A total of $5 \times 10^{5}$ cells were seeded on to six-well plates and cultured until $80-90 \%$ confluent. The cells were transiently transfected for $16 \mathrm{~h}$ with plasmid constructs and $\beta$-galactosidase plasmid using Lipofectamine, according to the manufacturer's protocol (Gibco-BRL, Burlington, Ontario, Canada). The medium was then changed for one containing different regulators $\left(25 \mu \mathrm{M}\right.$ forskolin; $16 \mathrm{mM} \mathrm{KCl} ; 10^{-7}$ M AII; $100 \mathrm{nM}$ staurosporine; $200 \mathrm{nM}$ bisindolylmaleimide; $16 \cdot 2 \mathrm{nM}$ 12-O-tetradecanoylphorbol 13 acetate (TPA); 1 mM dBtcAMP; $1 \mu \mathrm{M}$ BAYK 8644; $10 \mu \mathrm{M}$ nifedipine) and cells were cultured for another 48 or $60 \mathrm{~h}$. The same concentrations of stimuli/inhibitors were used in experiments in which aldosterone production and CAT activity were determined. Cell lysates were prepared by freezethawing, and CAT activity was assayed by silica gel thin layer chromatography using $\left[{ }^{14} \mathrm{C}\right]$ chloramphenicol (Gorman et al. 1982); radioactivity was quantified using an optical imager (PhosphorImager SF, Molecular Dynamics, Sunnyvale, CA, USA). CAT activity was calculated as the percentage of chloramphenicol converted to acetylated forms and corrected for transfection efficiency with the corresponding $\beta$-galactosidase activity ( $\beta$-Gal ELISA; Boehringer-Mannheim GmbH, Mannheim, Germany). All experiments were performed in triplicate and repeated at least three times. Statistical significance was determined using a Mann-Whitney $\mathrm{U}$ test, and a value of $P<0.05$ was considered significant.

\section{Steroid quantification}

The level of aldosterone in incubation media was measured by the Coat-A-Count RIA procedure (Diagnostic Products, Los Angeles, CA, USA).

\section{RESULTS}

\section{Effects of regulators on aldosterone output of NCI-H295 cells}

Significant increases over the basal level of aldosterone were produced (mean \pm s.E.M., $n=3$, $P<0.001)$ by forskolin $(360 \pm 24 \%)$, dBtcAMP $(550 \pm 9 \cdot 8 \%)$, AII $(430 \pm 21 \cdot 3 \%)$, bisindolylmaleimide $(300 \pm 4 \cdot 1 \%), \mathrm{KCl}(430 \pm 13 \cdot 9 \%)$ and $\mathrm{BAYK}$ $8644(520 \pm 15 \cdot 5 \%)$, and decreases by staurosporine $(63 \pm 7 \cdot 8 \%)$ and TPA $(25 \pm 3 \cdot 9 \%)$. Nifedipine had no effect on the basal level of aldosterone but it 
completely prevented the increases produced by both BAYK 8644 and $\mathrm{KCl}$.

\section{Effects of regulators on the expression of CAT} activity in NCI-H295 cells

In a first series of experiments, we investigated the effects of the above mentioned regulators on the $-486 \mathrm{bp}$ construct. This $-486 \mathrm{bp}$ region of the 5'-UTR of CYP11B2 gene showed promoter activity that was stimulated by dBtcAMP and forskolin (720 and 300\% respectively) (Fig. 2B). AII also stimulated CAT activity (450\%) (Fig. 2A), whereas TPA, a known stimulator of the protein kinase C (PKC) signaling pathway, had no significant effect. However, with a specific inhibitor of the PKC signaling pathway, namely bisindolylmaleimide, a $340 \%$ increase in CAT activity was obtained. Staurosporine, a broad spectrum inhibitor of kinases, reduced CAT activity to one third of control value.

$\mathrm{KCl}$ stimulated CAT activity by $700 \%$ (Fig. 2C) while the calcium channel activator BAYK 8644 showed an increase of $820 \%$. The calcium channel antagonist nifedipine had no effect on CAT activity but prevented the increases produced by both BAYK 8644 and $\mathrm{KCl}$, demonstrating the involvement of calcium channels in the mode of action of $\mathrm{KCl}$ on the transcription of $C Y P 11 B 2$.

\section{Expression of basal CAT activity}

Ten deletion plasmids were used to study the promoter regulatory regions of the hamster $C Y P 11 B 2$ gene. As shown in Fig. 3, basic and TATA box plasmids showed only a small background CAT activity. Compared with the basic plasmid containing no $C Y P 11 B 2$ insert, the promoter activity gradually and significantly $(P<0.05)$ increased with the augmentation of the length of deletion plasmids containing respectively the putative cis-elements Ad1, Ad2 and Ad5; a peak of activity was reached with the $-167 \mathrm{bp}$ construct, containing the -143 / - 161 cis- element. A significant $(P=0 \cdot 001)$ decrease in CAT activity occurred thereafter with the -328 pb construct containing $\mathrm{Ad} 3$, to increase again with longer constructs.

\section{Effects of AII and $\mathrm{KCl}$ on the expression of CAT activity by the ten deletion plasmids}

As shown in Fig. 4, AII (middle panel) and $\mathrm{KCl}$ (lower panel) significantly $(P<0.05)$ stimulated the expression of the reporter gene of all constructs except those of basic and TATA box. A peak of activity $(600 \%$ with $\mathrm{AII} ; 1000 \%$ with $\mathrm{KCl})$ occurred
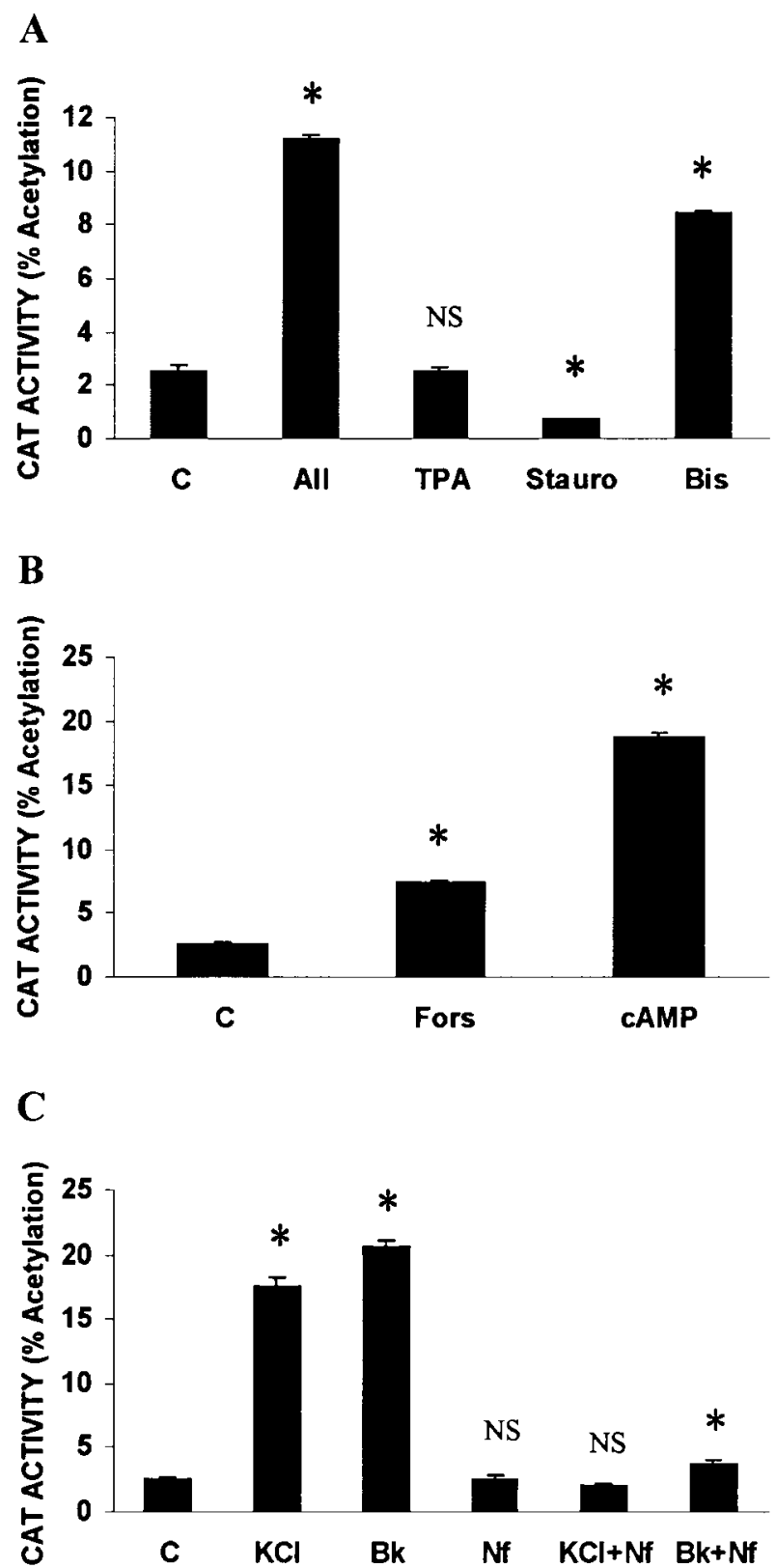

FIGURE 2. Effects of various regulators on CAT gene expression upon transfection of NCI-H295 cells with the $-486 \mathrm{bp}$ construct. At $16 \mathrm{~h}$ after transfection, the medium was changed for one containing different regulators. (A) Control (C); $10^{-7} \mathrm{M}$ angiotensin II (AII); $16 \cdot 2 \mathrm{nM} 12-O$-tetradecanoylphorbol 13-acetate (TPA); $100 \mathrm{nM}$ staurosporine (Stauro); $200 \mathrm{nM}$ bisindolylmaleimide (Bis). (B) Control (C); $25 \mu \mathrm{M}$ forskolin (Fors); $1 \mathrm{mM}$ dBtcAMP (cAMP). (C) Control (C); $16 \mathrm{mM} \mathrm{KCl;} 1 \mathrm{mM}$ BAYK 8644 (Bk); $10 \mu \mathrm{M}$ nifedipine (Nf), and cells were cultured for another 48 or $60 \mathrm{~h}$. Results shown are representative of three experiments performed in triplicate (means \pm s.E.M.). * $P<0 \cdot 05$, experimental vs control. NS, not significant. 


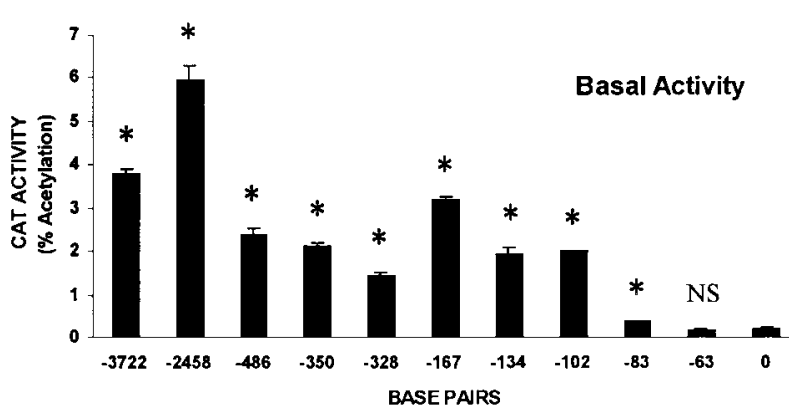

FIGURE 3. Basal transcriptional activities of truncated hamster CYP11B2 gene promoters. NCI-H295 cells were transfected with the basic plasmid containing no CYP11B2 insert and with various deletion plasmids, and cultured for $48 \mathrm{~h}$. Transfection efficiency was standardized by $\beta$-galactosidase analysis as described in Materials and Methods. Results shown are from one experiment representative of three experiments performed in triplicate (means \pm s.E.M.). $* P<0 \cdot 05$, compared with the basic plasmid containing no CYP11B2 insert. NS, not significant.

when the $-167 \mathrm{bp}$ deletion plasmid which contains the $-143 /-161$ cis-element was used. Compared with the $-167 \mathrm{bp}$ construct, the relative increase was significantly $(P=0 \cdot 02)$ smaller with the deletion plasmid containing the putative Ad3 cis-element; with longer constructs, the percentage increase returned towards that of the $-167 \mathrm{bp}$ construct.

\section{Mutation in the $-143 /-161$ cis-element of the hamster CYP11B2 gene}

As mentioned above, a peak of basal CAT activity and also AII- and $\mathrm{KCl}$-stimulated activity occurred when NCI-H295 cells were transfected with the $-167 \mathrm{bp}$ deletion plasmid which contains the $-143 /-161$ cis-element. This region was thus mutated in the Ad4 construct to study its implication in the $C Y P 11 B 2$ gene regulation. Fig. 5 shows that mutation of the $-143 /-161$ cis-element decreased basal CAT activity, although not significantly. However, the stimulating effects of all regulators on the mutant CAT activity were significantly lower than those of the wild type. These results thus confirm that the $-143 /-161$ cis-element is necessary to maintain a high level of $C Y P 11 B 2$ transcriptional activity in NCI-H295 cells.

\section{DISCUSSION}

In this work we report that the $5^{\prime}$-UTR of the hamster $C Y P 11 B 2$ gene possesses promoter activity that can be stimulated by $\mathrm{AII}, \mathrm{KCl}$, forskolin, $\mathrm{dBtcAMP}$ and bisindolylmaleimide. These results
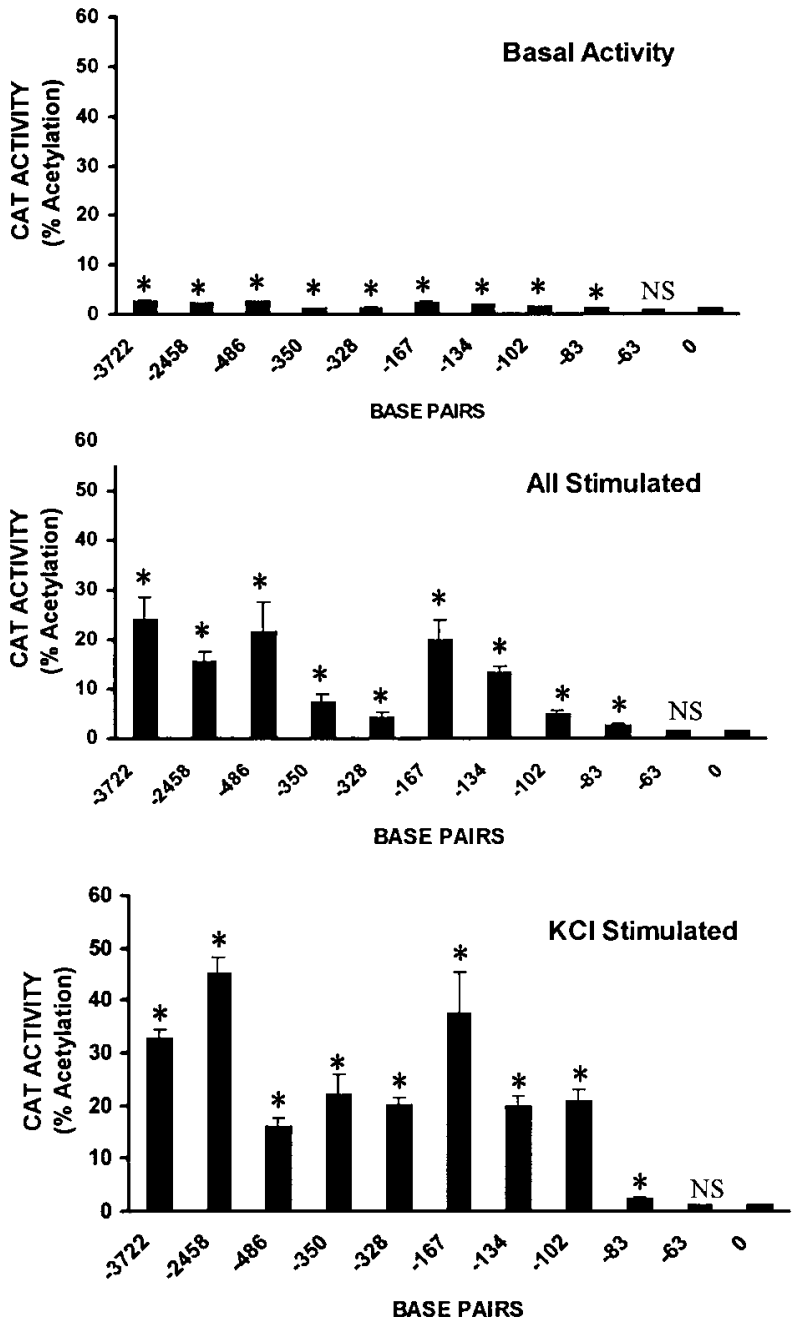

FIgURE 4. Basal, AII- and KCl-stimulated transcriptional activities of truncated hamster $C Y P 11 B 2$ gene promoters. NCI-H295 cells were transfected with the basic plasmid containing no $C Y P 11 B 2$ insert and with various deletion plasmids and cultured for $48 \mathrm{~h}$ without (basal promoter activity, upper panel) or with $10^{-7}$ M AII (middle panel) or $16 \mathrm{mM} \mathrm{KCl}$ (lower panel). Transfection efficiency was standardized by $\beta$-galactosidase analysis as described in Materials and Methods. Results shown are from one experiment representative of three experiments performed in triplicate (means \pm S.E.M.). ${ }^{*} P<0 \cdot 05$; comparisons were made between deletion plasmids and the basic plasmid containing no CYP11B2 insert. Comparisons were also made for each plasmid between stimulated and non-stimulated conditions. NS, not significant.

were obtained using the CAT assay carried out on NCI-H295 cells that were transfected with $C Y P 11 B 2$ deletion plasmids. These deletion plasmids were constructed to study the effects of conserved sequences among the rat, mouse, human 

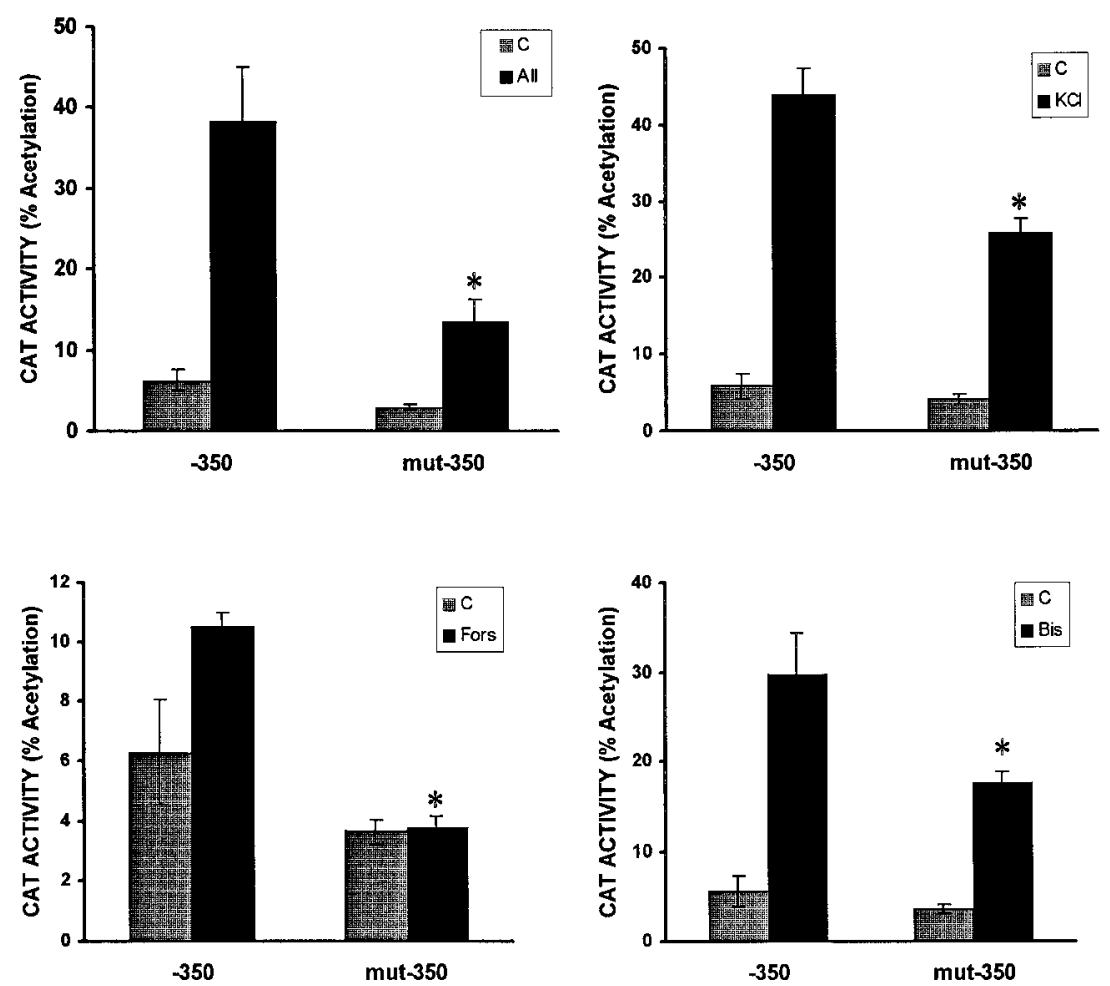

FIGURE 5. Mutation of the $-143 /-161$ cis-element in the Ad4 construct. The sequence $5^{\prime}$-ggtaagacacttctactga- 3 ' was changed to 5'-aagacatggtaccatagct-3'. Basal as well as AII-, KCl-, bisindolylmaleimideand forskolin-stimulated CAT activities were determined. When compared with the wild type (-350), all CAT activities were diminished with the mutant (mut-350). Results shown are the mean \pm s.E.M. from one experiment performed in triplicate using three different plasmid preparations, and representative of three different experiments. $* P<0 \cdot 05$; in the four conditions studied, the stimulated CAT activity of the mut-350 was significantly lower than that of the wild type -350 .

and hamster $C Y P 11 B 2$ genes, namely $\mathrm{Ad} 1, \mathrm{Ad} 2$, Ad5, Ad3 and Ad4 (Honda et al. 1990, Morohashi \& Omura 1990, Lala et al. 1992), and a newly reported conserved sequence between $-143 \mathrm{bp}$ and $-161 \mathrm{bp}$ of the 5'-UTR of the hamster gene (Coulombe et al. 1996, 1997). In NCI-H295 cells, a peak in basal transcription occurred with the -167 bp construct which contains many cis-elements, namely Ad1, a known cAMP cis-element in the mouse $c y p 11 b 2$ gene (Mouw et al. 1989), Ad2, Ad5 and the -143/-161 cis-element. However, when Y1 cells were transfected with the same hamster CYP11B2 deletion plasmids, it was not the $-167 \mathrm{bp}$ construct that showed the highest transcriptional activity; on the contrary, its activity was lower than that of the -134 construct, suggesting an inhibitory function for the $-143 /-161$ bp cis-element in Y1 cells (Coulombe et al. 1996, 1997). These opposing results indicate the possibility that interactions between the -143 /
- 161 cis-element and other binding protein(s) may differ between NCI-H295 and Y1 cells. Indeed, positive or negative regulation in this region of the gene could well depend upon the presence, the absence, or a difference in concentration of specific binding protein(s) in these two cell types. In contrast with NCI-H295 cells, Y1 cells do not produce aldosterone because they lack certain steroidogenic enzymes. This strongly suggests the possibility of deficient expression of important transcription factor(s) involved in the expression of steroidogenic genes in Y1 cells. The presence of a putative inhibitory sequence between the Ad5 and Ad4 cis-elements of the mouse cyp11b2 gene has also been reported in transfection studies using Y1 cells (Bogerd et al. 1990). This inhibitory sequence on the mouse cyp $11 b 2$ gene corresponds to a sequence of the hamster $C Y P 11 B 2$ promoter located upstream of the $-143 /-161$ cis-element but overlapping it by 
five nucleotides. In contrast, no such inhibitory ciselements have been found in the first $-2015 \mathrm{bp}$ of the 5'-UTR of the human CYP11B2 gene (Clyne et al. 1997).

Forskolin and cAMP stimulate the transcriptional activity of hamster $C Y P 11 B 2$ deletion plasmids in NCI-H295 cells, demonstrating participation of the protein kinase A signaling pathway in modulating the expression of this gene. This is in agreement with results obtained using Y1 cells (Coulombe et al. 1996, 1997).

Under the experimental conditions used, an addition of $10^{-7} \mathrm{M}$ ACTH to the incubation medium of NCI-H295 cell culture did not induce significant increases in either aldosterone or cortisol production; this is why we did not study the effect of ACTH on hamster CYP11B2 promoter activity. Our results are in agreement with those published by Clyne et al. (1996), who found that ACTH provoked an increase in the human $C Y P 11 B 2$ promoter activity in transfected $\mathrm{Y} 1$ but not NCI-H295 cells. The lack of response of NCIH295 cells may tentatively be attributed to the low level of ACTH receptor expression in these cells (Rainey et al. 1993, Mountjoy et al. 1994), or to an unknown defect located between ACTH receptor and adenylate cyclase, since, as shown in this report, $\mathrm{dBtcAMP}$ and also forskolin were able to induce the hamster $C Y P 11 B 2$ promoter activity.

In contrast with Y1 cells (Coulombe et al. 1997), in NCI-H295 cells, AII and $\mathrm{KCl}$ were able to stimulate the promoter activity of the hamster $C Y P 11 B 2$ gene. The concentration $10^{-7} \mathrm{M}$ AII was chosen because it has been shown to maximally stimulate aldosterone production in NCI-H295 cells (Bird et al. 1993). The reported stimulatory effects of AII on the transcriptional activity of the mouse (Holland et al. 1995) and human (Clyne et al. 1996) CYP11B2 promoter in NCI-H295 cells are in agreement with our results. More recently, the same group (Clyne et al. 1997) identified two cis-elements in the human $C Y P 11 B 2$ promoter that are required for full basal reporter gene activity and for maximal induction by either cAMP or calcium signaling pathways. One of these cis-elements resembles a consensus cAMP response element; the other, located in the Ad5 area, demonstrated binding of the orphan nuclear receptors SF-1 and chicken ovalbumin upstream promoter transcription factor (COUP-TF), as determined by the absence of binding in the presence of antibodies directed against SF-1 and COUP-TF. In human CYP11B2 gene, the last seven nucleotides TGACCTT in the Ad5 area involved in the binding of SF-1 forms an SF-1-like sequence. A similar sequence is not present in the Ad5 area of the hamster, rat and mouse CYP11B2 genes, and therefore $\mathrm{SF}-1$ is unlikely to contribute to the enhancing effect observed with the hamster CYP11B2 - $134 \mathrm{bp}$ deletion plasmid containing the putative Ad5 cis-element. In our study, maximal AII or $\mathrm{KCl}$ stimulation occurred with the $-167 \mathrm{bp}$ transfectant which contains the previously mentioned -143/ - 161-protected cis-element. This cis-element was mutated to further evaluate its importance to CYP11B2 promoter activity. Mutations were effected on the $-350 \mathrm{bp}$ deletion plasmid containing Ad4 in order to allow interactions with other putative regulatory factors that could intervene beyond the mutated region. The basal CAT activity of the mutant fell but was not significantly decreased compared with that of the wild type. However, stimulation by $\mathrm{KCl}$, AII, forskolin and bisindolylmaleimide was significantly less with the mutant, indicating that this cis-element is important in maintaining a full response of transcriptional activity to these regulators.

Our results showing that nifedipine inhibited the stimulatory effect of $\mathrm{KCl}$ on the transcriptional activity of $C Y P 11 B 2$ and on aldosterone output are in agreement with the report of Bird et al. (1995), who showed that this calcium channel antagonist blocked the $\mathrm{KCl}$-induced aldosterone output in NCI-H295 cells. Potassium acts by increasing intracellular calcium through the opening of nifedipinesensitive voltage-dependent calcium channels of the plasma membrane (Rainey et al. 1993). Taken together these results indicate that the entry of calcium plays an important role in the stimulatory action of $\mathrm{KCl}$ on aldosterone synthase promoter activity and aldosterone synthesis in NCI-H295 cells. Moreover, Pezzi et al. (1997) have reported that treatment with either calmidazolium, a calmodulin inhibitor, or KN93, an inhibitor of calmodulindependent kinases, completely inhibited potassiumstimulated expression of P450aldo mRNA with little effect upon AII- or dBtcAMP-stimulated induction of the transcript. This suggests that potassium, cAMP and AII effects on transcriptional activity may be secondary to differences in signaltransduction mechanisms.

In this study we used $16 \mathrm{mM} \mathrm{KCl}$ to stimulate NCI-H295 cells since this dose was reported to give maximal aldosterone production (Rainey et al. 1994). Also, Bird et al. (1995) showed a dosedependent increasing effect of potassium up to $16 \mathrm{mM}$ on P450C17 mRNA but not on that of $3 \beta$-HSD mRNA, demonstrating the specificity of the stimulus towards specific genes and indicating that these effects are of physiological significance.

The fact that bisindolylmaleimide, a potent and selective inhibitor of PKC (Toullec et al. 1991), 
stimulated both the transcriptional activity of hamster $C Y P 11 B 2$ deletion plasmids and aldosterone output of transfected NCI-H295 cells suggests that the PKC pathway plays a negative regulatory role in aldosterone synthesis. Furthermore, and in agreement with this interpretation, prolonged incubation with TPA, the activator of PKC, did not increase $C Y P 11 B 2$ transcriptional activity. It has also been reported (Clyne et al. 1996) that TPA has no effect on the activity of human CYP11B2 promoter in NCI-H295 cells. Thus the chronic stimulatory action of AII on transcription of hamster $C Y P 11 B 2$ appears not to be mediated through a PKC pathway. The effect of shorter incubation times with TPA on hamster $C Y P 11 B 2$ promoter activity was not studied in this work. However, Bird et al. (1993) reported that short-term treatment of NCI-H295 cells with AII resulted in a $450 \%$ increase in total inositol phosphates and in a significant increase in aldosterone output, indicating that the acute effect of AII on aldosterone output is mediated by inositol phosphates.

Staurosporine lowered $C Y P 11 B 2$ transcriptional activity and aldosterone output in NCI-H295 cells, but had a stimulatory effect on the transcriptional activity of the $C Y P 11 B 2$ gene and on steroid output in Y1 cells (Reyland 1993, Coulombe et al. 1997). Staurosporine, although a potent inhibitor of PKC, is poorly selective when assayed against other protein kinases (Toullec et al. 1991), and discrepancies between the response of the two cell types to this product can also be tentatively explained by differences in the signaling pathways between NCI-H295 and Y1 cells, the latter being deficient, as previously mentioned, in expressing certain steroidogenic genes involved in aldosterone, cortisol and dehydroepiandrosterone synthesis. Also, the difference observed between the effects of staurosporine and bisindolylmaleimide might be due to the presence in NCI-H295 cells of PKC isoenzymes which may be affected differently by various inhibitors and activators.

In conclusion, we found that the $5^{\prime}$-UTR of the hamster CYP11B2 gene in transfected NCI-H295 cells possesses transcriptional activity that can be stimulated by $\mathrm{AII}, \mathrm{KCl}$, forskolin, dBtcAMP and bisindolylmaleimide. Our results suggest that this gene is regulated, at least in part, through the protein kinase A signaling pathway and through calcium channels, whereas PKC might negatively regulate the transcription of the $C Y P 11 B 2$ gene. We have shown that the cis- element $-143 /-161$ in the $5^{\prime}$-UTR of the hamster CYP11B2 gene is important in maintaining high promoter activity in NCI-295H cells.

\section{ACKNOWLEDGEMENTS}

We are grateful to Dr D Shapcott for invaluable advice and to Dr W E Rainey for providing NCI-H295 cells. This work was supported by a grant from the Medical Research Council of Canada (MT10983), and the Heart and Stroke Foundation of Canada.

\section{REFERENCES}

Bird IM, Neil A, Hanley R, Word RA, Mathis JM, McCarthy JL, Mason JI \& Rainey WE 1993 Human NCI-H295 adrenocortical carcinoma cells: a model for angiotensin-IIresponsive aldosterone secretion. Endocrinology 133 1555-1561.

Bird IM, Mathis M, Mason JI \& Rainey WE 1995 $\mathrm{Ca}^{2+}$-regulated expression of steroid hydroxylases in H295R human adrenocortical cells. Endocrinology 136 5677-5684.

Bogerd AM, Franklin A, Rice DA, Schimmer BP \& Parker KL 1990 Identification and characterization of two upstream elements that regulate adrenocortical expression of steroid $11 \beta$-hydroxylase. Molecular Endocrinology 4 845-850.

Clyne CD, White PC \& Rainey WE 1996 Calcium regulates human CYP11B2 transcription. Endocrine Research 22 485-492.

Clyne CD, Zhang Y, Slutsker L, Mathis JM, White PC \& Rainey WE 1997 Angiotensin II and potassium regulate human CYP11B2 transcription through common cis-elements. Molecular Endocrinology 11 638-649.

Coulombe N, Lefebvre A \& LeHoux JG 1996 Characterization of the hamster $C Y P 11 B 2$ gene regulatory regions. Endocrine Research 22 653-661.

Coulombe N, Lefebvre A \& LeHoux JG 1997 Characterization of the hamster $C Y P 11 B 2$ gene encoding adrenal cytochrome P450 aldosterone synthase. DNA and Cell Biology 16 993-1002.

Domalik LJ, Chaplin DD, Kirman MS, Wu RC, Liu W, Howard TA, Seldin MF \& Parker KL 1991 Different isoenzymes of mouse $11 \beta$-hydroxylase produce mineralocorticoids and glucocorticoids. Molecular Endocrinology 5 1853-1861.

Gazdar AF, Oie HK, Shackelton CH, Chen TR, Triche TJ, Myers CE, Chrousos G.P, Brennan MF, Stein CA \& LaRocca RV 1990 Establishment and characterization of a human adrenocortical carcinoma cell line that expresses multiple pathways of steroid biosynthesis. Cancer Research 50 5488-5496.

Gorman CM, Moffat LF \& Howard BH 1982 Recombinant genomes which express chloramphenicol acetyl transferase cells. Molecular and Cellular Biolology 2 1044-1051.

Holland OB, Carr B \& Brasier AR 1995 Aldosterone synthase gene regulation by angiotensin. Endocrine Research 21 455-462.

Honda SI, Morohashi KI \& Omura T 1990 Novel cAMP regulatory elements in the promoter region of bovine $\mathrm{P}-450$ (11ß) gene. Fournal of Biochemistry 108 1042-1049.

Imai M, Shimada H, Okada Y, Matsushima-Hibiya Y, Ogishima T \& Ishimura Y 1990 Molecular cloning of a cDNA encoding aldosterone synthase cytochrome P450 in rat adrenal cortex. FEBS Letters 263 299-302.

Lala DS, Rice DA \& Parker KL 1992 Steroidogenic factor I, a key regulator of steroidogenic enzyme expression, is the mouse homolog of fushi tarasaru-factor I. Molecular Endocrinology 6 1249-1258. 
LeHoux JG \& Tremblay A 1992 In vivo regulation of gene expression of enzymes controlling aldosterone synthesis in rat adrenal. Fournal of Steroid Biochemistry and Molecular Biology 43 837-846.

LeHoux JG, Mason JI, Bernard H, Ducharme L, LeHoux J, Véronneau S \& Lefebvre A 1994 The presence of two cytochrome $\mathrm{P} 450$ aldosterone synthase mRNAs in the hamster adrenal. Fournal of Steroid Biochemistry and Molecular Biology 49 131-137.

LeHoux JG, Bernard H, Ducharme L, Lefebvre A, Shapcott D, Tremblay A \& Véronneau S $1996 a$ The regulation of the formation of glucocorticoids and mineralocorticoids in vivo. Advances in Molecular and Cellular Biology 14 149-201.

LeHoux JG, Lefebvre A, Ducharme L, Lehoux J, Martel D \& Brière N $1996 b$ Some effects of a low sodium intake on the expression of $\mathrm{P} 450$ aldosterone synthase in the hamster adrenal cortex: immunoblotting, immunofluorescent and immuno-gold electron microscopic studies. Fournal of Endocrinology 149 341-349.

Miller WL 1988 Molecular biology of steroid hormone synthesis. Endocrine Review 9 295-318.

Mornet E, Dupont J \& White PC 1989 Characterization of two genes encoding human steroid 11 $\beta$-hydroxylase (P45011 $\beta)$. Fournal of Biological Chemistry 26 20961-20967.

Morohashi KI \& Omura T 1990 Tissue-specific transcription of P-450(11ß) gene in vitro. Fournal of Biochemistry 108 $1050-1056$.

Morohashi K, Nomaka Y, Kirita S, Hatano S, Takakusu A, Okamoto M \& Omura T 1990 Enzymatic activities of $\mathrm{P} 450(11 \beta)$ s expressed by two cDNAs in COS 7 cells. Fournal of Biochemistry 107 635-640.

Mountjoy KG, Bird IM, Rainey WE \& Cone RD 1994 ACTH induces up-regulation of ACTH receptor mRNA in mouse and human adrenocortical cell lines. Molecular and Cellular Endocrinology 199 R17-R20.

Mouw AR, Rice DA, Meade JC, Chua SC, White P, Schimmer BP \& Parker KL 1989 Structural and functional analysis of the promoter region of the gene encoding mouse

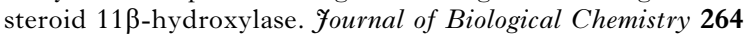
1305-1309.

Nomura M, Morohashi KI, Kirita S, Nanoka Y, Okamoto M, Nawata H \& Omura T 1993 Three forms of rat $C Y P 11 B$ genes: $11 \beta$-hydroxylase gene, aldosterone synthase gene, and a novel gene. Fournal of Biochemistry 113 144-152.

Pezzi V, Clyne CD, Ando S, Mathis JM \& Rainey WE 1997 $\mathrm{Ca}^{2+}$-regulated expression of aldosterone synthase is mediated by calmodulin and calmodulin-dependent protein kinases. Endocrinology 136 5677-5684.
Rainey WE, Bird IM, Sawetawan C, Hanley NA, McCarthy JL, McGee EA, Wester R \& Mason JI 1993 Regulation of human adrenal carcinoma cell (NCI-H295) production of C19 steroids. Fournal of Clinical Endocrinology and Metabolism 77 731-737.

Rainey WE, Bird IM \& Mason JI 1994 The NCI-H295 cell line: a pluripotent model for human adrenocortical studies. Molecular and Cellular Endocrinology 100 45-50.

Reyland ME 1993 Protein kinase C is a tonic negative regulator of steroidogenesis and steroid hydroxylase gene expression in Y1 adrenal cells and functions independently of protein kinase A. Molecular Endocrinology 7 1021-1030.

Toullec D, Pianetti P, Coste H, Bellevergue P, Grand-Perret T, Ajakane M, Baudet V, Boissin P, Boursier E, Loriolle F, Duhamel L, Charon D \& Kirilovsky J 1991 The bisindolylmaleimide GF $109203 \mathrm{X}$ is a potent and selective inhibitor of protein kinase C. Fournal of Biological Chemistry 266 15771-15781.

Tremblay A \& LeHoux JG 1992 Influence of captopril on adrenal cytochrome P-450 s and adrenodoxin expression in high potassium or low sodium intake. Fournal of Steroid Biochemistry and Molecular Biology 41 799-808.

Tremblay A \& LeHoux JG 1993 Transcriptional activation of adrenocortical steroidogenic genes by high potassium or low sodium intake. FEBS Letters 317 211-215.

Tremblay A, Waterman MR, Parker KL \& LeHoux JG 1991 Regulation of rat adrenal messenger RNA and protein levels for cytochrome $\mathrm{P} 450 \mathrm{~s}$ and adrenodoxin by dietary sodium depletion of potassium intake. Fournal of Biological Chemistry $2662245-2251$.

Tremblay A, Parker KL \& LeHoux JG 1992 Dietary potassium supplementation and sodium restriction stimulate aldosterone synthase but not $11 \beta$-hydroxylase P450 messenger ribonucleic acid accumulation in rat adrenals and require angiotensin II production. Endocrinology 130 $3152-3158$

Véronneau S, Bernard H, Cloutier M, Courtemanche J, Ducharme L, Lefebvre A, Mason JI \& LeHoux JG 1996 The hamster adrenal cytochrome P450C11 has equipotent $11 \beta$-hydroxylase and 19-hydroxylase activities, but no aldosterone synthase activity. Fournal of Steroid Biochemistry and Molecular Biology 57 125-139.

Yanagibashi K, Haniu M, Shively JE, Shen WH \& Hall P 1986 The synthesis of aldosterone by the adrenal cortex, two zones (fasciculata and glomerulosa) possess one enzyme for $11 \beta, 18$-hydroxylation, and aldehyde synthesis. Fournal of Biological Chemistry 261 3556-3562.

RECEIVED 10 July 1997 